\section{Para una nueva abstracción ${ }^{1}$}

José Cruz Ovalle Arquitecto, Escola Tècnica Superior d'Arquitectura de Barcelona.

Para José Cruz, la arquitectura constituye una toma de posición que es capaz de medirse con las palabras. Una nueva abstracción orienta su campo de trabajo que se sitúa entre el arte -concretamente la escultura- $y$ la arquitectura. Materiales, formas constructivas y relaciones espaciales se alternan como huellas de un proceso de reflexión creativa.

I / Es posible que algunos arquitectos hayan tenido una experiencia en común: la de esa persona que acude a encargar una obra y lleva recortes de revistas con distintos rincones o fragmentos. Es que puede ver partes más no el total. Pues la totalidad supone ver relaciones. Desde las partes se puede alcanzar lo completo pero no lo íntegro que supone una totalidad como requiere una obra de arquitectura. Lo íntegro se alcanza con la simultaneidad de varias dimensiones, en cambio lo completo se obtiene por la mera suma de sus partes. Es un asunto de grados en la elaboración del pensamiento.

La arquitectura podría concebir su tamaño habitable como desprendimiento del cielo abierto. Totalidad inalcanzable. Mirar tal cosa es simplemente un modo de orientarse -creativamente hablando- mediante la invención de lo que podría ser una suerte de lejanía topológica. Pues toda orientación requiere de algún punto en la lejanía. Pero aquello que pueda ser el tamaño habitable, la totalidad, o la lejanía, así como lo íntegro o lo completo, son asuntos que cada obra disputa a su modo, ya que a la arquitectura no le es dado pensar desde la generalidad como a la filosofía, sino a partir de casos únicos.

Lo anterior puede ser ese paso previo para introducir lo que se entiende por abstracción: un camino que requiere de un lenguaje que no generaliza, pues cada oficio necesita su propia palabra, cosa hoy perdida, pues el habla se ha vuelto homogénea. Se supone que la palabra es trasladable desde y hacia cualquier ámbito, y que el pensamiento filosófico o científico es directamente utilizable. Se trata ciertamente de la construcción de una utopía: la utopía del acceso inmediato. Esta traslación directa del lenguaje, conlleva -por así decirlo- un quantum analógico que confiere al razonamiento un primer grado de figuración que le impide abrirse a lo que intenta pensar. ${ }^{2}$

Es necesario precisar que figuración y abstracción no se entienden como opciones diferentes, pero equivalentes, sino como grados distintos de elaboración del pensamiento; asunto evidente si atendemos a que desde la figuración no es posible comprender la abstracción en cambio esta última abarca -por decirlo así- a la primera. Abstracción y figuración no son términos absolutos y homogéneos sino graduaciones que van desde lo más elemental, como puede ser una noción que se endereza desde la representación literal de una determinada realidad, hasta aquella elaboración capaz de constituirse, por sí misma, en presencia de una realidad otra.

Pureza del espacio y simplicidad de la forma, acompañada por la neutralidad de la materia y la geometría de figuras elementales, son representaciones figurativas de la abstracción, que provienen de una mirada, sobre ciertas obras de la vanguardia artística del s. xx, que ve la forma como pura generación.

Por cierto, la arquitectura actual entiende la generación como origen; más que estar urgida (ungida?) por la forma lo está por la posibilidad. Esto impide advertir que aquellas formas fueron el paso necesario para construir la obra

\section{For a new abstraction ${ }^{1}$}

José Cruz Ovalle Architect, Escola Tècnica Superior d'Arquitectura de Barcelona

For José Cruz, architecture consists of taking a position capable of being measured in words. A new abstraction orients his body of work the lies between art -specifically sculpture- and architecture. Materials, built forms and spatial relationships are alternated like the footprints in the process of creative reflection.

I / Every architect has no doubt been faced on some occasion with a potential client who brings in a pile of magazine clippings showing various corners or fragments. The problem in such situations is that one can see parts of what is wanted but not the total project, because totality presupposes relationships. From the various parts one can attain completion but not the whole, for the latter implies the totality that a work of architecture requires. The whole is achieved through the simultaneity of various dimensions, whereas completion is the mere sum of the parts. It is a matter of gradations in the development of thinking.

Architecture may conceive of its habitable size as a detached expanse of "open sky". Unreachable totality. Observing a thing is simply a way of orienting oneself, creatively speaking, by inventing a sort of topological distance, for every orientation is relative to some point in the distance. But habitable size, totality, distance, the whole and completion, all these are notions that each work disputes in its own fashion, since in architecture one cannot reason from generality as one can in philosophy, and therefore must do so from individual cases.

The foregoing may serve as a preface to the introduction of what we understand by abstraction: a path that requires a language that does not generalize. Each craft needs its own word, something that has been lost in this day and age when expression has become homogeneous. Presumably this word is transferable from and to any domain, and philosophical or scientific thought is directly utilizable. One might say that this direct transfer of language brings with it an analogous "quantum" that confers upon reasoning a first degree of figuration preventing it from opening itself to what it is trying to reason. ${ }^{2}$

It should be clarified here that figuration and abstraction are not to be understood as different though equivalent "options," but rather as distinct levels of development of thinking. This is obvious once we consider that although figuration does not allow us to comprehend abstraction, abstraction does include, so to speak, figuration. Abstraction and figuration are not absolute, homogeneous terms but rather gradations that range from the most elemental, such as a notion that arises from a literal representation of a given reality, to a creation able to materialize itself in the presence of some reality that is "other".

Purity of space and simplicity of form, accompanied by the neutrality of material and the geometry of elemental figures, etc., are figurative representations of abstraction originating in a vision of certain works by avant-garde artists of the 20th century that sees form as pure generation.

Architecture today sees generation as origin, and is preoccupied with possibility rather than form. This tends to obscure the fact that those forms were a necessary step for constructing works as pure presence. For the first time, the artistic transcendence of a work was manifested as the perfection of its own immanence; the work sang the presence of what was there before 
' Ensayo introductorio del libro José Cruz Ovalle. Hacia una nuevo abstracción (2004)

${ }^{2}$ Tratándose de la arquitectura y de la escultura, debe tenerse presente que la palabra no es determinable como en la filosofía en la que significado y sentido coinciden. Po significado y sentido coinciden. Por sentido de la abstracción propuesta sin aludir a la experiencia de cada caso, ocasiona la pérdida de una dimensión fundamental.

${ }^{3}$ Mediante la abstracción es posible encontrarse con la extensión como dimensión del quehacer arquitecdimensión del quehacer arquitectónico, abierta por Amereida y por el pensamiento de la Escue

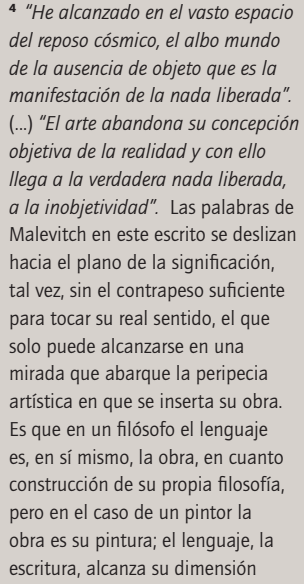

4 "He alcanzado en el vasto espacio de la ausencia de objeto que de la ausencia de objeto que es la manifestación de la nada liberada". objetiva de la realidad y con ello llega a la verdadera nada liberada, a la inobjetividad". Las palabras de Malevitch en este escrito se deslizan hacia el plano de la significación tal vez, sin el contrapeso suficiente para tocar su real sentido, el que solo puede alcanzarse en una mirada que abarque la peripecia artística en que se inserta su obra. Es que en un filósofo el lenguaje Es que en un flosofo el lenguaje construcción de su propia filosofi pero en el caso de un pintor la obra es su pintura; el lenguaje, la escritura, alcanza su dimensión

referido a la pintura y no puede mirarse aisladamente.

${ }^{5}$ Que una obra de arquitectura pueda nombrarse finalmente como edificio o una determinada investigación del espacio escultura resulta en este sentido indiferente: obra ya existe y su realidad desborda ciertamente la generalidad de un nombre que no es más que una convención del lenguaje. Pero que la palabra esté al inicio, supone que ella encierra la representación previa de lo que se acomete.

6 La finalidad concluye una generalidad que la acoge: una visión totalizante que se dice a si misma que solo siendo totalizante es visión.
1 Introductory essay from the book José Cruz Ovalle. Hacia una nueva abstracción (2004)

${ }^{2}$ Since we are speaking here of architecture and sculpture, it mus be kept in mind that the word is not determinable as it is in philosophy. where signified and sense coincide. where signimed and sense coincide. of the sense or meaning of a proof the sense or meaning of a pro-
posed abstraction without alluding to the experience of each individual case would result in the loss of a fundamental dimension.

${ }^{3}$ Through abstraction we may encounter extension as a dimension oncounter extension as a dimension by the Open City Amereida and the school of thought associated with the Valparaiso School of Architecture.

4 "I have found in the vast space of cosmic repose the white world of the absence of object that is the manifes. tation of liberated nothingness"... "Art abandons its objective conception of reality and thus reaches true liberated nothingness: inobjectivity." Malevich's words in this passage slip into the plane of signification, perhaps without a sufficient counterweight that would enable them to express their true meaning, which can only be grasped in a vision encompassing the artistic peripeteia that was

the backdrop to his work. For the philosopher language itself is the work, the construction of his own philosophy, whereas for the painter

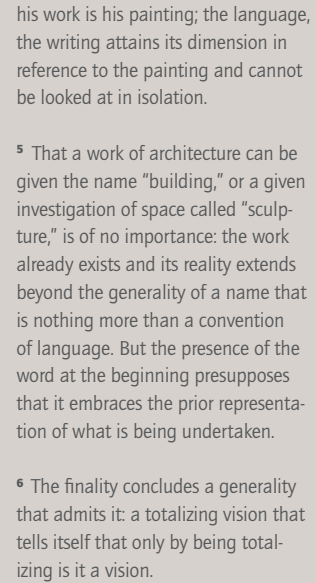

6 The finality concludes a generality that admits it: a totalizing vision that tells itself that only by being totalzing is it a vision.

como pura presencia. Por vez primera la trascendencia artística de una obra tiene lugar como perfección de su propia inmanencia; la obra canta la presencia de lo que está allí, ante nuestros ojos, sin remitirnos a lo que está fuera, más allá, mediante su representación. La abstracción abrió con esto un cambio radical: liberó al ojo de ese previo representar que antecede a la primera mirada.

Ni las formas elementales ni la neutralidad de la materia en la búsqueda de una pureza tienen hoy relación con la abstracción. Desde la proposición por recoger y elaborar las múltiples dimensiones del acontecer, puede entenderse que una obra de arquitectura se inicie con la concepción de un tamaño habitable que desprendido del cielo abierto se encuentra con la extensión, primera luz que le da medida y orientación ${ }^{3}$. Después podrá venir el espaciamiento del vacío interno que busca sus límites... pero eso ya requiere de una mirada de cada obra para no generalizar, pues esta abstracción cuida no entrar en generalidades.

II / El paso decisivo consiste para Malevitch en abandonar el objeto para borrar con su ausencia todo vestigio de representación de la realidad exterior, pero también cualquier intención direccionada hacia un objetivo: la inobjetividad, como aquella ausencia que podría abrir la pintura a una abstracción total, manifestación de la nada liberada, pura presencia. ${ }^{4}$

Ciertamente, el intento de concebir una obra tiende a asirse a un representar y en este sentido es el objeto quien se nos aproxima desde su condición de atrapabilidad. No miramos ya el objeto al modo de Malevitch; más que la inobjetividad como principio para crear libre de finalidades objetivas, se trata de la ausencia de objeto planteada para un desprendimiento en el inicio.

Es que el objeto, en virtud de su conclusividad, lleva consigo una potencia de tematización que anticipa una representación a lo que se intenta concebir: una imagen. Podría ser la de edificio, en el caso de una obra de arquitectura; la de escultura, en el caso de una forma de investigación del espacio, o la de cuadro en el caso de una pintura. ${ }^{5}$

Tal representación situada en su inicio es, de suyo, una generalidad, en cambio la realidad de cada obra la abre a una singularidad. A diferencia de Malevitch y la vanguardia no vamos ya en esa abstracción de la generalidad sino en esta de la singularidad.

Una nueva abstracción en el sentido que admite grados, no de aquella abstracción universal propuesta por las vanguardias que se encaminaba hacia su consumación en la idea de una totalidad única al modo de esa ciudad que veía el Neoplasticismo. ${ }^{6}$

Visión de la nueva polis que avanzaba a su cumplimiento como destino final del arte, el que podría integrarse finalmente a la vida de un hombre nuevo. ${ }^{7}$

La creación artística iba, así, inscrita en una temporalidad direccionada hacia un designio; sin embargo, para nuestra mirada, el arte no se inserta en una our eyes without referring us to what lay outside, beyond, through its representation. Abstraction thus cleared the way for a radical change in that it liberated the eye from the prior act of representing which precedes the first view.

Today, neither elemental forms nor neutrality of material in the search for purity have any relation to abstraction. From the perspective of including and developing the many dimensions of the present as a presence, a work of architecture can be seen as beginning from a conception of a habitable size that, once detached from the open sky, takes on an extension, the first light that gives it measure and orientation. ${ }^{3}$ Later may come the spacing of the internal vacuum that seeks its limits... but that would require a vision of each work so as not to generalize, for this abstraction takes care to avoid generalizations.

II / For Malevich the decisive step is the abandonment of the object so as to erase not only every vestige of representation of external reality, but also every intention directed toward an objective. Non-objectivity is the absence that can open painting up to a total abstraction, the "manifestation of liberated nothingness", pure presence. ${ }^{4}$

Attempts to conceive a work undoubtedly tend to have recourse to an act of representation, and in this sense it is the object that approaches us by virtue of its capturability. We no longer look at the object as did Malevich. Rather than inobjectivity as the principle for creating "free of objective ends", it is a matter of the object's absence as a separation from the beginning.

By virtue of its conclusivity, an object brings with it an ability to thematize that anticipates a representation of what one is attempting to conceive: an image. It could be the image of "building" in the case of architecture, or "sculpture" in the case of an investigation of space, or "picture" in the case of a painting. ${ }^{5}$

Such a representation situated at its beginning is in itself a generality, whereas the reality of each work makes possible its singularity. Unlike Malevich and the avant-garde we are no longer dealing with the abstraction of generality, but rather that of singularity.

A new abstraction in the sense that it allows gradations, not the universal abstraction proposed by the avant-gardes which marched off toward its own consummation through the idea of a unique totality in the style of the city as visualized by Neoplasticism.

A vision of a new polis that advanced toward its realization as art's final destination, which in the end could be integrated into the life of a new man. ${ }^{7}$

Artistic creation was thus positioned in a temporality directed toward a specific goal. To our eyes, however, art does not have a direction as part of a historical process, but rather exists in a multiple present.

This song of art to the peripeteia of progress and the beauty in the unity of all in the construction of the world was without doubt a reason for art but not 
7 iViva la Ou Nov Is que crea afirma lo nuevo en el mundo!", so las palabras finales del manifiesto de Suprematista. Un arte que pasa a la ciudad, a la vida política y pública, como planteaba el escultor vasco Jorge Oteíza, heredero de la vanguardi Final y finalidad del arte en aquel momento en que cesa la actividad del artista para que sus conquistas pasen a los demás (haciendo un nuepasen a los demás (haciendo un nuevo hombre, espiritual y políticamente transformado por el arte).

8 "iViva el sistema unido de la arquitectura mundial de la tierra!" puede leerse en el manifiesto suprematista.

9 Origen como acto radical propio para el arte es, en este caso, aque que recompone el pensamiento en cada obra, pues no se parte de una generalidad -de un punto cero general "de una vez para todas"- sino de casos únicos no generalizables. "Volver a no saber" habían dicho el poeta Godofredo Iommi y el arquitecto Alberto Cruz Cada obra inaugura de este modo un nuevo tiempo, para situarnos, asi, en ese múltiple presente y no en en ese miltiple presente yno en el transcurso de un desenvolvimien to historico. Es que esta abstracción supone pasar desde el transcurso a la simultaneidad.

${ }^{10}$ Lo finiquitado del objeto y su homogeneidad es visible hoy en el diseño y su relación con la arquitectura cuyos términos se han invertido. Se diseña una obra, en tanto esta puede iniciarse y apoyars en el diseño -en su condición de finiquito fáctico-, esto le confiere la homogeneidad de un objeto; por cierto, de gran tamaño.

" Nuestra civilización piensa las obras como un logro, porque en ella el logro es una realidad cierta. Es un asunto que radica en la interna positividad de la ciencia y de la técnica.

12 La arquitectura en su dar casa abre lugar a que la técnica entre a precisar. Pero actualmente estos términos suelen invertirse, es la técnica la que da lugar a la arquitectura. El diseño, que pertenece de suyo al objeto es,

13 Ni la arquitectura ni el arte pueden agotar su propia realidad. Malevitch, al igual que la vanguardia pensó que el arte podía agotar su propio deci.

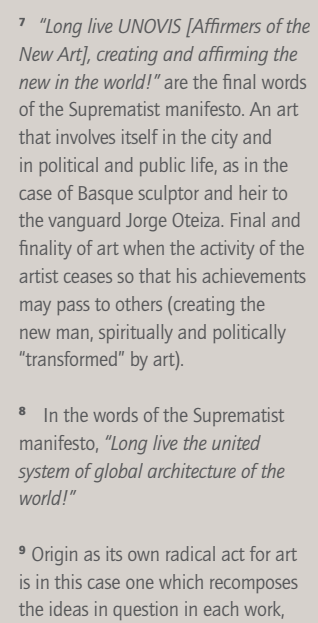

"Long live UNOVIS [Affirmers of the New Art]. creating and affirming the new in the world!" are the final word of the Suprematist manifesto. An art of the Suprematist manifesto. An art
that involves itself in the city and that involves itself in the city and in political and public life, as in the the vanguard Jorge Oteiza. Final and finality of art when the activity of the finality of art when the activity of the may pass to others (creating the may pass to others (creating the
new man, spiritually and politically "transformed" by art.

8 In the words of the Suprematist manifesto, "Long live the united system of global architecture of the world!"

${ }^{9}$ Origin as its own radical act for art is in this case one which recomposes the ideas in question in each work,

for one does not start from a generality, a zero point as a "once and for all" general law, but rather from individual cases that cannot be generalized. "Return to not knowing" said the poet Godofredo lommi and the architect Alberto Cruz. Each work inaugurates in this manner a new ime to situate us in that multiple than in a historical development. Abstraction means moving from the passage of time to simultaneity.

${ }^{10}$ The finalization of the object and its homogenization is visible today in design and its relationship to architecture, whose terms have been architecture, whose terms have been
reversed. A work is "designed" to the extent it can be initiated and supported by the design as a real finalization, giving it the homogeneity of an object - no doubt a large one.

1 Our civilization thinks about works as the realization or the achievement of something because for us, achievement is a sure reality. It is a notion rooted in the internal positivity of science and technique.

12 By virtue of its "hosting" or "sheltering," architecture enables technique to impose precision. But in current usage these terms tend to be reversed. Thus, it is technique that enables architecture. Design, which belongs to the object by its very nature, is therefore what generates a work.

3 Neither architecture nor art can exhaust its own reality. Malevich, like the avant-garde, felt that art could exhaust its own expression. dirección como desenvolvimiento histórico sino en un múltiple presente.

Ese canto del arte a la peripecia del progreso y la belleza de la unidad de todos en la construcción del mundo era, ciertamente, razón para el arte pero no su origen: un trasfondo social pero no propiamente artístico. ${ }^{8}$

Es que para dar origen al arte se requiere de un acto. Este dice que no se lo concibe ya como arte en su generalidad, sino desde cada obra, lo que supone un nuevo comienzo en el acto radical del desprendimiento: ese volver cada $v e z$ al inicio. Esto es ir en la singularidad de los casos únicos, no generalizables y que constituyen la real autonomía de la obra. A diferencia de Malevitch lo radical es este nuevo inicio cada vez y no aquel de una vez para todas. ${ }^{9}$ El objeto y la objetividad suponen para Malevitch la imposibilidad de un punto cero -nada liberada- como estado de pureza desde el cual comenzar el arte a partir de una verdad inobjetiva universal. Pero aquí se trata de preguntarse por aquella dimensión del objeto que cierra esta abstracción propuesta. Lo propio del objeto es de suyo lo finiquitado, que como tal no admite hiato 0 abertura en su propio finiquito. ${ }^{10}$

Para la vanguardia, en su temporalidad de progreso no hay lugar para pensar la diferencia entre finiquito y conclusividad artística. En tal sentido no se abre ningún hiato o rasgadura en el interior de la obra. Ellos van dentro de ese movimiento que avanza en la construcción del mundo y pueden ser dueños de la totalidad en la seguridad de sus razones. De la totalidad de ese logro con el que se piensa la obra. ${ }^{11}$

En este sentido la técnica carece de hiato porque la conclusividad técnica es de suyo finiquito fáctico. No da cabida a que lo ilimitado de una obra tenga ciertamente un límite. Porque la técnica como dominio puro, hace imposible en su propia esencia una inconclusividad fáctica. ${ }^{12}$

Desde el punto de vista del arte, una obra, a diferencia de un objeto, es ilimitada porque no puede agotar aquello que acomete. ${ }^{13}$ Pero en razón de que lo ilimitado es inalcanzable, su límite no termina de cerrarla, dejando este hiato o abertura.

La confianza en la técnica nace de pensar que ésta puede agotar lo que acomete. Ciertamente puede cerrarlo pero no lo agota, pues no pone un límite a lo ilimitado sino que construye lo limitado mismo.

El abandono de la abstracción universal por su concepción totalizante, hizo girar el arte desde la libertad de formas, conquistada por la vanguardia, a la libertad de acción; aquella del artista, que puede volverse dueño del acto creador. Un giro que va desde la obra a la persona del artista.

Pero esta nueva abstracción propone, así, otro giro diferente: uno que sucede al interior de la obra misma. ARa

\section{Bibliografía sugerida}

Crispiani, Alejandro y Elizabeth Bennett, editores. José Cruz Ovalle. Hacia una nueva abstracción. Ediciones ARQ, Santiago, 2004. / Subirats, Eduardo. La flor y el cristal: Ensayos sobre arte $y$ arquitectura modernos. Editorial Anthropos, Barcelona, 1986. its origin: a social dimension but not, properly speaking, an artistic one. ${ }^{8}$

To originate art requires an act. This means that one does not conceive of "art" in its generality but rather in terms of each individual work, which implies a new beginning in the radical act of separation, a return each time to the start. It means proceeding via the singularity of individual cases, not generalizable, which together constitute the true autonomy of a work. In contrast to Malevich, what is radical is this new beginning each time, not the beginning that is once and for all.

An object and objectivity imply for Malevich the impossibility of a zero point - "liberated nothingness"- a state of purity from which to initiate art based on an unobjective universal truth. But here we must ask about the dimension of the object that concludes this proposed abstraction. What is intrinsic to the object is what is finalized, and which as such admits of no hiatus or opening in its own finalization..$^{10}$

For the avant-garde, in their temporality of progress there is no room for thinking in terms of a difference between finalization and artistic conclusivity. In this sense there is no hiatus or tear in the interior of the work. They proceed within this movement that advances in the construction of the world, and are able to be the masters of totality in the certainty of their reasons, the totality of that realization or achievement employed in thinking about the work. ${ }^{11}$

In this sense, technique has no hiatus because technical conclusivity is in itself a real finalization. There is no allowance for the unlimited nature of a work to have sure limits, because technique, as pure mastery, makes a real inconclusivity in its own essence impossible. ${ }^{12}$

From the point of view of art, a work, unlike an object, is unlimited because it cannot exhaust what it undertakes. ${ }^{13}$ But since the unlimited is unreachable, its limits never finish closing it, thus leaving a hiatus or opening.

The belief in technique is born of the idea that it can exhaust what it undertakes. Without a doubt technique can close but not exhaust it, for instead of putting limits on the unlimited, technique constructs the limited itself.

The abandonment of universal abstraction due to its totalizing concept redirected the course of art away from the freedom of form attained by the avant-garde and toward freedom of action, freedom for the artist to become the master of the act of creation. A change of course from the work of the artist to the artist himself.

But this new abstraction proposes a different change of course, one that takes place in the interior of the work itself. are

\section{Bibliography}

Crispiani, Alejandro and Elizabeth Bennett, editors. José Cruz Ovalle. Hacia una nueva abstracción. Ediciones ARQ Santiago, 2004. / Subirats, Eduardo. La flor y el cristal: Ensayos sobre arte y arquitectura modernos. Anthropos Press, Barcelona, 1986. 